\title{
Hypomagnesemia and its relation with chronic low-grade inflammation in obesity
}

\author{
Ana Raquel Soares de Oliveira ${ }^{1}$, Kyria Jayanne Clímaco Cruz ${ }^{1}$, Juliana Soares Severo², Jennifer Beatriz Sillva Morais², \\ Taynáh Emannuelle Coelho de Freitas ${ }^{3}$, Rogério Santiago Araújo4, Dilina do Nascimento Marreiro5*

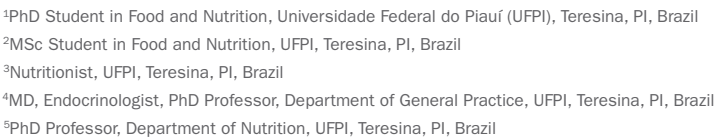

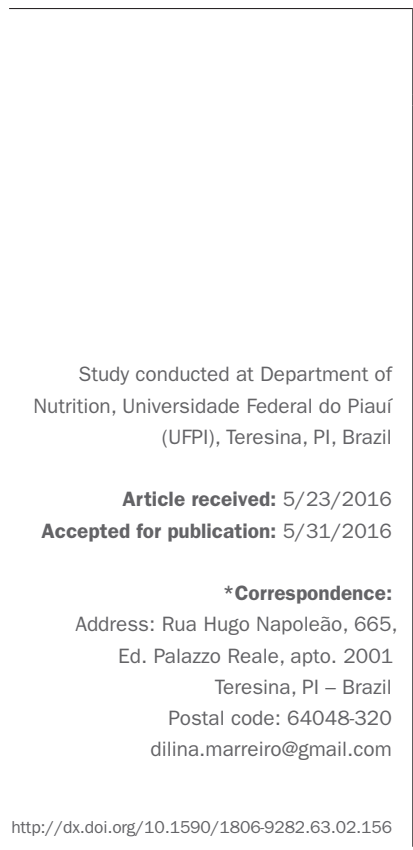

\section{SUMMARY}

Introduction: The accumulation of visceral fat in obesity is associated with excessive production of proinflammatory adipokines, which contributes to low-grade chronic inflammation state. Moreover, the literature has shown that mineral deficiency, in particular of magnesium, has important role in the pathogenesis of this metabolic disorder with relevant clinical repercussions.

Objective: To bring updated information about the participation of hypomagnesemia in the manifestation of low-grade chronic inflammation in obese individuals.

Method: Articles published in PubMed, SciELO, LILACS and ScienceDirect, using the following keywords: "obesity," "magnesium" and "low grade inflammation." Results: Scientific evidence suggests that magnesium deficiency favors the manifestation of low-grade chronic inflammation in obese subjects.

Conclusion: From literature data, it is evident the participation of magnesium through biochemical and metabolic reactions in protecting against this metabolic disorder present in obesity.

Keywords: obesity, magnesium, low-grade inflammation.

\section{INTRODUCTION}

White adipose tissue is the main energy source in the body, mobilizing fatty acids according to metabolic need. ${ }^{1}$ In excessive amounts, this tissue produces proinflammatory adipokines, a process influenced by the anatomical location of fat deposits. Visceral fat, being metabolically more active, favors an increase in the production of these substances, contributing to chronic low-grade inflammation in obesity. ${ }^{2,3}$

Low-grade chronic inflammation differs from other types of inflammation as it leads to latent tissue damage for extended periods of time, lasting for decades, silently., Studies have shown that in obese individuals the inflammatory state favors an increase in the formation of reactive oxygen species that can lead to an overload of the antioxidant defense system, contributing to the manifestation of oxidative stress and, consequently, cell damage and death. ${ }^{4,5}$

Biochemical and nutritional disorders present in obese individuals are being extensively investigated in order to elucidate the mechanisms involved in the pathogenesis of obesity. In this sense, minerals have been the subject of extensive research in order to identify their relation with metabolic disorders.

Magnesium in particular has attracted great interest from researchers as it plays a role in glucose metabolism, insulin homeostasis, synthesis of adenosine triphosphate, proteins and nucleic acids, as well as in membrane stability and regulation of hormonal and immunological function. ${ }^{6,7}$

Magnesium deficiency is characterized as a nutritional problem that leads to changes in the cellular function and biological activity of the molecules, and may contribute to the onset of metabolic disorders related to the inflammatory process, especially in obese individuals, who present low serum and dietary concentrations of this mineral. ${ }^{8-10}$

In view of the biochemical and metabolic aspects of magnesium, as well as the importance of the functions of this mineral, particularly in mechanisms involved in 
the pathogenesis of chronic diseases such as obesity, the objective of this review was to bring updated information on the participation of hypomagnesemia in the manifestation of low-grade chronic inflammation in obese individuals.

\section{Method}

The literature search was carried out in PubMed, SciELO, LILACS and ScienceDirect databases with no restrictions as to year of publication, considering the following inclusion criterion: studies on the metabolic and physiological aspects of magnesium, which presented relevant aspects on the role of this mineral in the manifestation of chronic low-grade inflammation in obese individuals. The articles were selected based on originality and relevance, taking into account the accuracy and adequacy of the experimental design and the sample number. Established and recent works were preferably used.

The search for bibliographic references was performed using the following keywords: "obesity," "magnesium" and "low grade inflammation." The literature search included the following types of studies: randomized or quasi-randomized controlled clinical trials, case-control study, and review articles.

\section{Metabolic and physiological aspects OF MAGNESIUM}

Magnesium is the second most abundant intracellular cation and is involved in about 300 biochemical reactions related to anabolic and catabolic actions in the body, such as glycolysis and protein and lipid metabolism. ${ }^{11}$ This mineral contributes to increase the production of intracellular adenosine triphosphate and the use of glucose, acting as a cofactor in all reactions that involve energy transfer. ${ }^{12}$

On average, the body of an adult contains 1 mole of magnesium. About half of the mineral content is present in the bone and the other half in soft tissues. More precisely, $0.3 \%$ of the total is found in serum, $0.5 \%$ in erythrocytes, $19.3 \%$ in soft tissues, $27 \%$ in muscles, and $52.9 \%$ in bones. In serum about one-third of the magnesium is bound to proteins. Of this total, $25 \%$ is bound to albumin and $8 \%$ to globulins. Of the remaining magnesium, about $80 \%$ is in the form of free ion (55\% of total magnesium) and about $20 \%$ is combined with phosphate, citrate and other compounds. ${ }^{13}$

Magnesium homeostasis in the body is dependent on the amount ingested, intestinal absorption, renal excretion and need presented by various tissues. ${ }^{11}$ About 25 to $60 \%$ of ingested magnesium is absorbed into the gastrointestinal tract by passive or active transport. The transport of this nutrient through the paracellular path- way is responsible for 80 to $90 \%$ of its absorption, which occurs predominantly between microvilli of the small intestine through simple diffusion, and this process is stimulated when intraluminal concentrations of this mineral are high. This absorption pathway occurs mainly in the ileum and distal parts of the jejunum, where the permeability to this ion is greater. This is because in these sites there is a low expression of claudin proteins $1,3,4$, 5 and 8 , which participate in the formation of paracellular barriers and pores, regulating the passage of substances through the epithelium. ${ }^{14-16}$

However, in the case of low intraluminal concentrations, the magnesium is absorbed through the action of specific transporters belonging to the family called transient receptor potential channel of melastatin type (TRPM6 and 7), and this process occurs by the active absorption of sodium ions, followed by water. ${ }^{17}$ This transport requires strict regulation since magnesium ions cross two cell membranes. The active absorption of the mineral occurs mainly in the colon and, to a lesser extent, in the jejunum and ileum. ${ }^{14-16}$

It is important to emphasize that excessive calorie intake promotes an increase in the intestinal absorption of magnesium, since the mechanism involved in this process is energy dependent. However, the absorption of this mineral can be impaired in the presence of lipids, phosphorus, phytates and oxalate. Diets low in protein ( $<30 \mathrm{~g} /$ day) also slow the absorption of magnesium. ${ }^{18,19}$

The kidneys are the main excreting organs involved in magnesium homeostasis, and $70 \%$ of the entire content of filtered mineral is reabsorbed in the thick ascending branch of the loop of Henle via the paracellular route. The driving force for magnesium reabsorption is positive transluminal epithelial tension generated by the recycling of potassium through the apical membrane, which is linked with sodium, water and calcium. In the distal convoluted tubule, magnesium transport mainly occurs by active process mediated by TRPM6, and is characterized by negative and highly resistant luminal tension, a specific process that does not depend on calcium absorption. ${ }^{20,21}$

In a situation of reduced oral intake of magnesium, the kidneys are able to reduce their excretion. The other routes of magnesium excretion are feces and sweat, with the fecal concentration of the mineral being about 150 to $200 \mathrm{mg} /$ day, while sweating contributes about $15 \mathrm{mg}$ daily loss. ${ }^{18,22}$ The balance of magnesium in the body is maintained by the regulation of urinary excretion, which can be exacerbated by the action of thyroid hormones, acidosis, aldosterone, and depletion of phosphate and potassium. On the other hand, calcitonin, glucagon and parathyroid hormone increase reabsorption of glomerular filtrate. ${ }^{23}$ 
The evaluation of nutritional status relative to magnesium can be obtained by assessing its contents in plasma, erythrocyte, urine and diet. Plasma magnesium has been widely used. However, this marker does not reflect its total content since, even after reduction in mineral intake, plasma concentrations remain constant for a long period of time. ${ }^{6,11}$ The reference values for normal plasma magnesium concentrations are between 0.75 and $1.05 \mathrm{mmol} / \mathrm{L} .^{18,19}$

Erythrocyte magnesium concentration is approximately $2.5 \mathrm{mmol} / \mathrm{L}$ and since it has a half-life of 120 days, medium and long-term evaluations of the mineral's stock in the body can be performed. ${ }^{24,25}$ As for urinary magnesium, approximately 3 to $4 \mathrm{mmol}$ of the nutrient is lost daily through this excretion route. Urine is considered a good indicator for recent changes in nutritional status regarding magnesium, because in cases of stock depletion, excretion is reduced by renal reabsorption mechanisms to maintain its homeostasis in the body. ${ }^{24}$

The main food sources of magnesium are whole grains, dark green vegetables, legumes, walnuts, seeds, chestnuts and almonds. ${ }^{26}$ The dietary recommendation of this mineral is 400 to 420 and 310 to $320 \mathrm{mg}$ daily for adult men and women, respectively. ${ }^{27}$

\section{Hypomagnesemia AND LOW-GRADE CHRONIC INFLAMMATION}

The literature has shown that the diet of obese individuals has reduced magnesium content, which is a nutritional problem of great relevance. ${ }^{28,29}$ Huang et al..$^{30}$ and Song et al. ${ }^{31}$ found that dietary intake of magnesium is inversely proportional to body mass index, waist circumference, and body fat percentage.

The reduced intake of magnesium by obese individuals can be explained mainly by the high consumption of processed foods containing low magnesium and by the reduced intake of food sources of magnesium, which seems to contribute to the reduction of its concentrations in the blood compartments. ${ }^{15}$

Studies have found reduced plasma concentrations of magnesium in obese individuals. ${ }^{32,33}$ Guerrero-Romero and Rodríguez-Morán ${ }^{34}$ have shown that individuals with normal body weight but metabolically obese exhibit reduced serum magnesium concentrations compared to the obese who are metabolically healthy. Table 1 shows data on the status of magnesium in obese individuals, as well as its participation in chronic low-grade inflammation.

Magnesium deficiency seems to affect the activation of proinflammatory pathways in obese individuals. ${ }^{40}$ In this regard, several researchers have observed that the reduced intake of this mineral and its low serum concen- tration are strongly related to the increase in the plasma concentration of inflammatory biomarkers, such as C-reactive protein, tumor necrosis factor alpha (TNF- $\alpha)$ and interleukin 6 (IL-6). ${ }^{26,33,41}$

Nielsen et al. ${ }^{42}$ found that magnesium intake in amounts below estimated average requirement (EAR) shows a positive correlation with plasma $\mathrm{C}$-reactive protein and body mass index in adults. Guerrero-Romero et al.$^{43}$ found severe hypomagnesemia in individuals with metabolic syndrome, being this parameter strongly related to serum concentrations of C-reactive protein and TNF- $\alpha$.

A study conducted by Oliveira et al. ${ }^{35}$ revealed reduced dietary magnesium content and urinary excretion in obese women. In addition, a positive correlation was observed between urinary magnesium and serum concentrations of C-reactive protein in these patients, suggesting the influence of hypomagnesuria on this inflammatory marker.

Reduced concentrations of magnesium in plasma compromise its intracellular homeostasis and contribute to the development of a proinflammatory state through overproduction and release of cytokines such as interleukin $1 \beta$ (IL-1 $\beta$ ) and TNF- $\alpha$, and increased serum concentrations of neuropeptides. ${ }^{11,44,45}$

It is important to mention that the mechanisms involved in the inflammatory response present in magnesium deficient obese individuals are not yet clearly elucidated. However, according to the literature, the opening of calcium channels and the activation of $\mathrm{N}$-methyl-D-aspartate (NMDA) receptors, as well as the priming of phagocytic cells, induce the entry of calcium into the cell, release of neurotransmitters, such as substance $P$, membrane oxidation and activation of nuclear transcription factor kappa B (NF-kB), which favors the inflammatory process. ${ }^{22,45,46}$

The inflammatory response is mainly related to the change in the extracellular concentration of magnesium, since the deficiency of this mineral reduces its plasma concentrations but does not alter its intracellular concentration. Thus, it is important to emphasize the action of magnesium as a natural calcium antagonist and that the reduction of magnesium in the extracellular compartment induces an increase in the concentration of intracellular calcium, favoring the activation of phagocytic cells and the production of cytokines. ${ }^{35,46}$

One of the mechanisms that seem to justify the increase of intracellular calcium is that of NMDA receptor activation. The decline in extracellular magnesium decreases the concentrations of amino acids such as glutamate needed to activate this receptor. Activation of NMDA, in turn, allows the influx of calcium into the neural cells. In the presence of obesity, this effect can be accentuated 
TABLE 1 Studies evaluating the status of magnesium in obese individuals or their relationship to chronic low-grade inflammation.

\begin{tabular}{ll} 
Author(s) & Study design \\
\hline Oliveira et al. $^{35}$ & 65 obese and 66 non-obese women \\
& Plasma, erythrocyte and urinary magnesium \\
& and C-reactive protein
\end{tabular}

\section{Results}

Obese women had plasma and erythrocyte magnesium

concentrations similar to the control group

Obese women had lower than normal values of magnesium in the urine

Correlation between urinary concentrations of magnesium and

C-reactive protein

\begin{tabular}{ll}
\hline Farhangi et al. ${ }^{9}$ & $\begin{array}{l}40 \text { obese and } 42 \text { non-obese women } \\
\text { Serum magnesium }\end{array}$ \\
\hline Cruz et al. ${ }^{10}$ & 55 obese and 59 non-obese women \\
& Plasma, erythrocyte and urinary magnesium
\end{tabular}

Obese women had lower serum magnesium concentrations than the control group

Obese women had plasma and erythrocyte magnesium

concentrations similar to the control group

Obese women presented values of urinary magnesium lower

than normal

\begin{tabular}{|c|c|c|}
\hline Zemva e Zemva ${ }^{36}$ & $\begin{array}{l}32 \text { obese and } 32 \text { non-obese individuals } \\
\text { Plasma and erythrocyte magnesium }\end{array}$ & $\begin{array}{l}\text { Obese individuals had lower plasma and erythrocyte magnesium } \\
\text { values compared to the control group }\end{array}$ \\
\hline Corica et al. ${ }^{37}$ & $\begin{array}{l}19 \text { obese normotensive, } 19 \text { obese hypertensive, } \\
\text { and } 15 \text { non-obese individuals } \\
\text { Plasma, erythrocyte and platelet magnesium }\end{array}$ & $\begin{array}{l}\text { Lower plasma, erythrocyte and platelet magnesium levels in the } \\
\text { normotensive and hypertensive obese group compared to the } \\
\text { control group }\end{array}$ \\
\hline Bertinato et al. ${ }^{38}$ & $\begin{array}{l}276 \text { southern Asian and } 315 \\
\text { Caucasian individuals. } \\
\text { Serum magnesium }\end{array}$ & $\begin{array}{l}\text { Obese women had lower serum magnesium values than normal } \\
\text { and overweight women }\end{array}$ \\
\hline Suliburska et al. ${ }^{39}$ & $\begin{array}{l}78 \text { obese and } 20 \text { non-obese adolescents } \\
\text { Serum magnesium }\end{array}$ & $\begin{array}{l}\text { Obese adolescents presented lower serum magnesium compared to } \\
\text { the control group }\end{array}$ \\
\hline Song et al. ${ }^{41}$ & $\begin{array}{l}11,686 \text { women aged } \geq 45 \text { years } \\
\text { Magnesium content in diet and plasma } \\
\text { C-reactive protein }\end{array}$ & $\begin{array}{l}\text { Inverse association between plasma C-reactive protein } \\
\text { concentrations and dietary magnesium content after adjustment for } \\
\text { age and body mass index }\end{array}$ \\
\hline Guerrero-Romero et al. ${ }^{43}$ & $\begin{array}{l}51 \text { women and } 47 \text { men } \\
\text { Serum magnesium, TNF- } \alpha \text { and C-reactive } \\
\text { protein }\end{array}$ & $\begin{array}{l}\text { Severe hypomagnesemia in individuals with metabolic syndrome, a } \\
\text { parameter strongly related to the serum concentrations of } \\
\text { C-reactive protein and TNF- } \alpha\end{array}$ \\
\hline Moslehi et al. ${ }^{57}$ & $\begin{array}{l}69 \text { overweight women } \\
\text { Serum magnesium and C-reactive protein, } \\
\text { and plasma IL- } 6 \\
\text { Supplementation with } 250 \mathrm{mg} / \text { day of } \\
\text { magnesium oxide for } 8 \text { weeks }\end{array}$ & $\begin{array}{l}\text { Magnesium serum concentrations were inversely correlated with } \\
\text { C-reactive protein before supplementation } \\
\text { However, supplementation with magnesium did not alter the serum } \\
\text { concentrations of this mineral, and did not reduce the levels of } \\
\text { C-reactive protein and IL-6 }\end{array}$ \\
\hline $\begin{array}{l}\text { Rodriguez-Hernandez } \\
\text { et al. }{ }^{58}\end{array}$ & $\begin{array}{l}38 \text { obese women } \\
\text { Serum magnesium and C-reactive protein } \\
\text { Supplementation with } 450 \mathrm{mg} / \text { day of } \\
\text { magnesium chloride for } 4 \text { weeks }\end{array}$ & $\begin{array}{l}\text { No reduction in C-reactive protein concentrations was observed in } \\
\text { obese women treated with supplements }\end{array}$ \\
\hline $\begin{array}{l}\text { Simental-Mendía } \\
\text { et al. }{ }^{59}\end{array}$ & $\begin{array}{l}62 \text { men and women diagnosed as pre-diabetic } \\
\text { Serum magnesium and C-reactive protein } \\
\text { Supplementation with } 382 \mathrm{mg} / \text { day of } \\
\text { magnesium chloride for } 12 \text { weeks }\end{array}$ & $\begin{array}{l}\text { Oral magnesium supplementation reduced levels of C-reactive } \\
\text { protein in subjects with pre-diabetes and hypomagnesemia }\end{array}$ \\
\hline Niranjan et al. ${ }^{60}$ & $\begin{array}{l}62 \text { obese children and } 60 \text { controls } \\
\text { Serum magnesium and C-reactive protein }\end{array}$ & $\begin{array}{l}\text { Reduced serum magnesium concentrations were seen in the case } \\
\text { group compared to the control, as well as of C-reactive protein }\end{array}$ \\
\hline
\end{tabular}


by leptin, a hormone that also favors the receptor's activation. ${ }^{40}$ Thus, excessive calcium influx into the neuronal tissue promotes the release of neurotransmitters, such as substance $\mathrm{P}$, which triggers an inflammatory response through the release of cytokines, histamine and free radicals $^{47}$ (Figure 1 ).

In adipose tissue, the increase of the intracellular calcium content derives from the opening of the L-type calcium channels, which is regulated by magnesium binding sites. In the presence of deficiency of this nutrient, the blockage of these channels is compromised, increasing the influx of calcium to the adipose cells. Excess intracellular calcium, in turn, results in the activation of calcium-dependent processes, such as the release of proinflammatory cytokines. Note that one of the major events in the calcium-mediated inflammatory process is the activation of NF-kB. ${ }^{46,48,49}$

$\mathrm{NF}-\mathrm{kB}$ is a potent proinflammatory gene transcription factor. When activated, it binds to specific genes, stimulating the production and release of the proinflammatory cytokines, namely TNF- $\alpha$ and IL- 6 , and adhesion molecules. These cytokines, when released in excess, favor the secretion of C-reactive protein by the liver. ${ }^{35}$

It is important to say that TRPM7 channels appear to regulate magnesium concentrations in tissues, and are therefore important in the homeostasis of this mineral. ${ }^{50}$ Note, however, that TRPM7 is not selective for magnesium, and its expression may also mediate calcium influx and consequently inflammation, which depends on the serum concentrations of both minerals. That is, in situations of magnesium deficiency, calcium competes with magnesium and enters the cells. ${ }^{51,52}$

Magnesium deficiency appears to increase the production of free radicals and the sensitivity of cells to the attack of reactive oxygen species. ${ }^{53,54}$ Hypomagnesemia favors the infiltration of neutrophils and macrophages in the affected cells, which potentiates the activity of the enzyme nicotinamide adenine dinucleotide phosphate oxidase

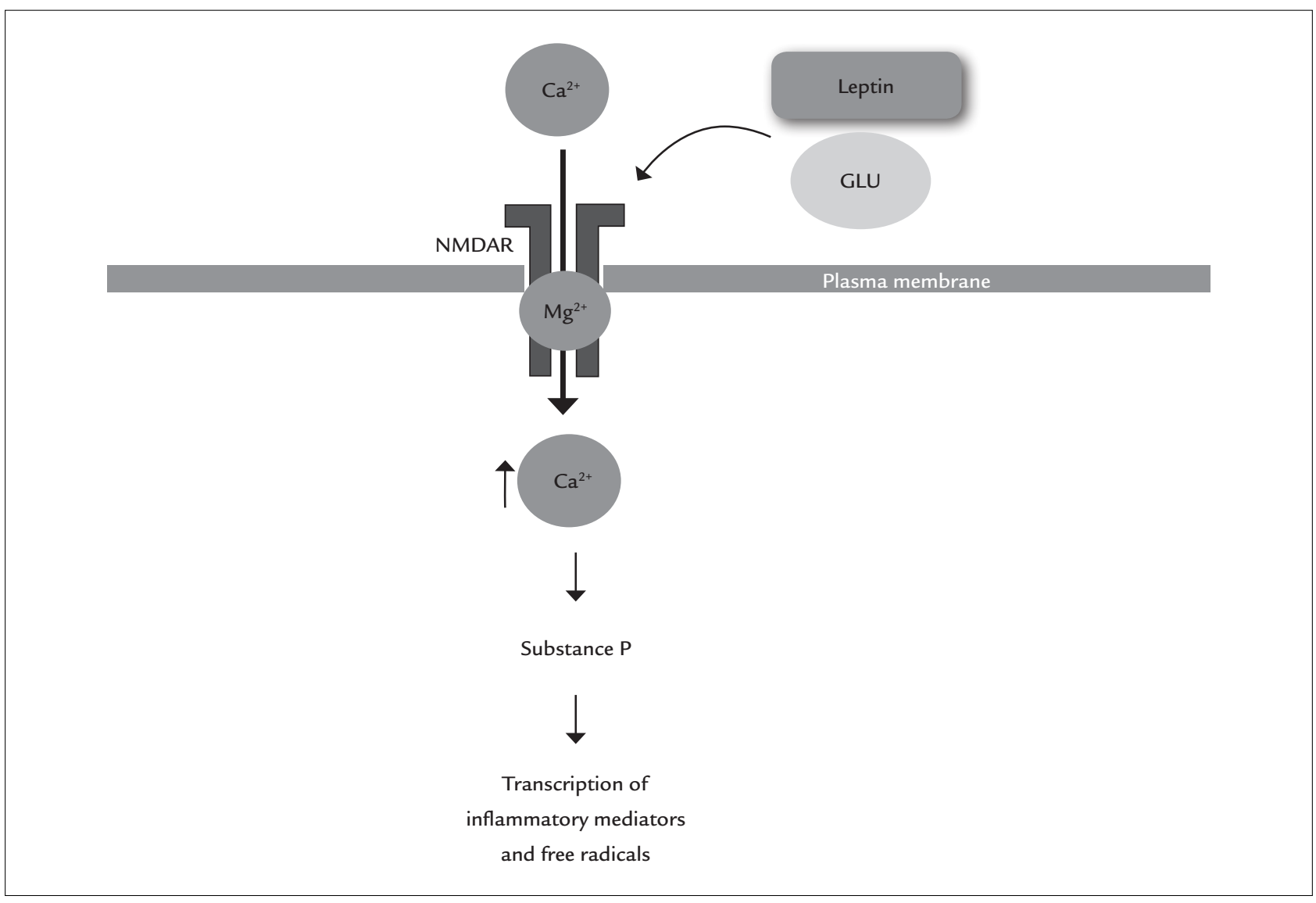

FIGURE 1 Action of magnesium as an anti-inflammatory nutrient in the brain. The increase of calcium in the intracellular medium promotes the transcription of inflammatory mediators through the release of substance P. Magnesium can inhibit this inflammatory pathway by its action as a natural calcium antagonist, blocking the increase of intracellular concentrations of this mineral. $\mathrm{Ca}^{2+}:$ calcium; $\mathrm{Mg}^{2+}$ : magnesium; NMDAR: N-methyl-D-aspartate receptor; GLU: glutamate. 
(NADPH oxidase), increasing the production of the superoxide radical. ${ }^{46,55}$

Hypomagnesemia also contributes to reduce the expression and activity of antioxidant enzymes, such as glutathione peroxidase (GPx), superoxide dismutase (SOD) and catalase (CAT), and cellular and tissue antioxidant concentrations, as well as increases the production of hydrogen peroxide by inflammatory cells. ${ }^{11,56}$

Combined with this, in the presence of hypomagnesemia, intracellular ionic calcium contributes to the excessive production of uric acid and hydroxyl radical, which reacts with nitric oxide, which is also high in hypomagnesemia, forming peroxynitrite. ${ }^{22,57}$ Thus, excessive production of reactive species in magnesium-deficient individuals also contributes to the inflammatory state present in obese individuals (Figure 2).

Some studies have been conducted to evaluate the effect of magnesium supplementation in obese or overweight individuals. However, no reduction in the concen- tration of inflammatory biomarkers was observed. Moslehi et $a .^{57}$ found that supplementation with $250 \mathrm{mg}$ /day of magnesium oxide for 8 weeks was not able to reduce levels of C-reactive protein in overweight women. Rodriguez-Hernandez et al..$^{58}$ did not observe reduced concentrations of this inflammatory protein in obese women supplemented with $450 \mathrm{mg}$ of magnesium chloride for 4 weeks, either.

\section{Final considerations}

Scientific evidence as presented in this review suggests that magnesium deficiency favors the manifestation of chronic low-grade inflammation in obese individuals. Nevertheless, mineral supplementation does not seem to influence the reduction of inflammatory biomarkers. Although some explanations have been proposed with a view to clarifying the role of the mineral in this disorder, the mechanisms are not yet fully identified. Therefore, new studies on the subject may provide biochemical

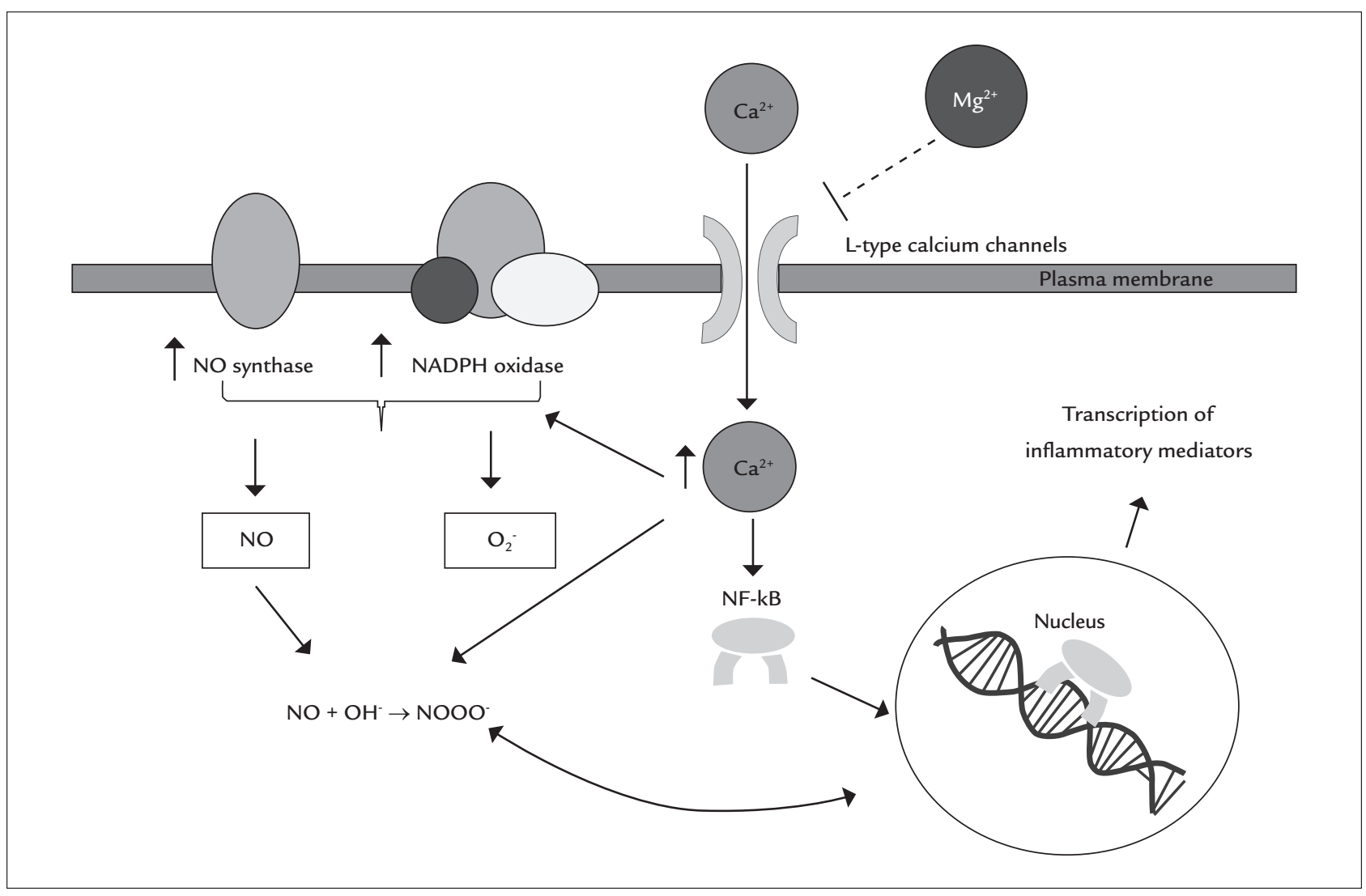

FIGURE 2 Action of magnesium as an anti-inflammatory nutrient in adipose tissue. The increase of calcium in the intracellular medium promotes the oxidation of cell membranes and the transcription of inflammatory mediators through the activation of NF- $\kappa \mathrm{B}$ and its translocation into the nucleus, and increases the oxidative stress through the activation of the NO synthase and NADPH oxidase. Magnesium can inhibit this inflammatory pathway by its action as a natural calcium antagonist, blocking the increase of intracellular concentrations of this mineral. $\mathrm{Ca}^{2+}$ : calcium; $\mathrm{Mg}^{2+}$ : magnesium; NF-KB: nuclear factor kappa B; $\mathrm{NO}$ synthase: nitric oxide synthase. 
bases to explain the action of this nutrient as a protection against chronic inflammation present in obesity.

\section{Conflict Of InTERest}

The authors declare no conflict of interest.

\section{Resumo}

Hipomagnesemia e sua relação com a inflamação crônica de baixo grau na obesidade

Introdução: $\mathrm{O}$ acúmulo de gordura visceral na obesidade está associado à produção excessiva de adipocinas pró-inflamatórias, o que contribui para o estado de inflamação crônica de baixo grau. A literatura também tem mostrado que a deficiência de minerais, em particular do magnésio, possui papel importante na patogênese desse distúrbio metabólico com repercussões clínicas relevantes. Objetivo: Trazer informações atualizadas sobre a participação da hipomagnesemia na inflamação crônica de baixo grau em indivíduos obesos.

Método: Bases de dados Pubmed, SciELO, Lilacs e ScienceDirect, utilizando as palavras-chave: "obesity", "magnesium" e "low grade inflammation".

Resultados: As evidências científicas sugerem que a deficiência de magnésio favorece a manifestação da inflamação crônica de baixo grau em indivíduos obesos.

Conclusão: É evidente a participação do magnésio, por meio de reações bioquímicas e metabólicas, na proteção contra esse distúrbio metabólico presente na obesidade.

Palavras-chave: obesidade, magnésio, inflamação crônica de baixo grau.

\section{References}

1. Lay SL, Simard G, Martinez MC, Andriantsitohaina R. Oxidative stress and metabolic pathologies: from an adipocentric point of view. Oxid Med Cell Longev. 2014; 2014:908539.

2. Ikeoka D, Mader JK, Pieber TR. Adipose tissue, inflammation and cardiovascular disease. Rev Assoc Med Bras (1992). 2010; 56(1):116-21.

3. França AKTC, Santos AM, Salgado JV, Hortegal EV, Silva AAM, Salgado Filho N. Estimated visceral adipose tissue, but not body mass index, is associated with reductions in glomerular filtration rate based on cystatin $\mathrm{C}$ in the early stages of chronic kidney disease. Int J Nephrol. 2014; 2014:574267.

4. Tunc O, Bakos HW, Tremellen K. Impact of body mass index on seminal oxidative stress. Andrologia. 2010; 43(2):121-8.

5. Zaki ME, El-Bassyouni H, Kamal S, El-Gammal M, Youness E. Association of serum paraoxonase enzyme activity and oxidative stress markers with dyslipidemia in obese adolescents. Indian J Endocrinol Metab. 2014; 18(3):340-4.

6. Elin RJ. Assessment of magnesium status for diagnosis and therapy. Magnes Res. 2010; 23(4):194-8.

7. Volpe SL. Magnesium in disease prevention and overall health. Adv Nutr. 2013; 4(3):378S-83S
8. Sales CH, Santos AR, Cintra DE, Colli C. Magnesium-deficient high-fat diet: effects on adiposity, lipid profile and insulin sensitivity in growing rats. Clin Nutr. 2014; 33(5):879-88

9. Farhangi MA, Ostadrahimi A, Mahboob S. Serum calcium, magnesium, phosphorous and lipid profile in healthy Iranian premenopausal women. Biochem Med. 2011; 21(3):312-20.

10. Cruz KJC, Oliveira ARS, Pinto DP, Morais JBS, Lima FS, Colli C, et al Influence of magnesium on insulin resistance in obese women. Biol Trace Elem Res. 2014; 160(3):305-10.

11. Barbagallo M, Dominguez LJ. Magnesium and aging. Curr Pharm Des. 2010; 16(7):832-9.

12. Khan AM, Sullivan L, McCabe E, Levy D, Vasan RS, Wang TJ. Lack of association between serum magnesium and the risks of hypertension and cardiovascular disease. Am Heart J. 2010; 160(4):715-20.

13. Elin RJ. Assessment of magnesium status. Clin Chem. 1987; 33(11):1965-70.

14. Baaij JHF, Hoenderop JGJ, Bindels RJM. Regulation of magnesium balance: lessons learned from human genetic disease. Clin Kidney J. 2012; 5(Suppl 1):i15-i24.

15. Jahnen-Dechent W, Ketteler M. Magnesium basics. Clin Kidney J. 2012; 5(Suppl 1):i3-i14.

16. Houillier P. Mechanisms and regulation of renal magnesium transport Annu Rev Physiol. 2014; 76:411-30.

17. Pham PC, Pham PM, Pham SV, Miller JM, Pham PT. Hypomagnesemia in patients with type 2 diabetes. Clin J Am Soc Nephrol. 2007; 2(2):366-73.

18. Bohl CH, Volpe SL. Magnesium and exercise. Crit Rev Food Sci Nutr. 2002; 42(6):533-63.

19. Martin KJ, González EA, Slatopolsky E. Clinical consequences and management of hypomagnesemia. J Am Soc Nephrol. 2009; 20(11):2291-5.

20. Silva RF, Beserra BTS, Oliveira ARS, Barbosa AM, Coelho JS, Poltronieri F, et al. Relação entre exercício físico, estresse oxidativo e magnésio. Nutrição em Pauta. 2013; 21:15-9.

21. Vetter T, Lohse MJ. Magnesium and the parathyroid. Curr Opin Nephrol Hypertens. 2002; 11(4):403-10.

22. Weglicki WB. Hypomagnesemia and inflammation: clinical and basic aspects. Annu Rev Nutr. 2012; 32:55-71.

23. Sales CH, Pedrosa LFC. Magnesium and diabetes mellitus: their relation. Clin Nutr. 2006; 25(4):554-62.

24. Gibson RS. Principles of nutrition assessment. 2. ed. New York: Oxford University Press; 2004.

25. Rocha VS. Avaliação bioquímica e do consumo alimentar de magnésio em mulheres saudáveis no terceiro trimestre gestacional [dissertation]. São Paulo: Faculdade de Ciências Farmacêuticas, Universidade de São Paulo; 2009.

26. Evangelopoulos AA, Vallianou NG, Panagiotakos DB, Eorgiou A, Zacharias GA, Alevra A, et al. An inverse relationship between cumulating components of the metabolic syndrome and serum magnesium levels. Nutr Res. 2008; 28(10):659-63

27. Institute of Medicine. Dietary reference intakes for calcium, phosphorus, magnesium, vitamin D, and fluoride. Washington: National Academy Press; 1997

28. Jarvandi S, Gougeon R, Bader A, Dasgupta K. Differences in food intake among obese and nonobese women and men with type 2 diabetes. J Am Coll Nutr. 2011; 30(4):225-32.

29. López-Alarcón M, Perichart-Perera O, Flores-Huerta S, Inda-Icaza P, Rodríguez-Cruz M, Armenta-Álvarez A, et al. Excessive refined carbohydrates and scarce micronutrients intakes increase inflammatory mediators and insulin resistance in prepubertal and pubertal obese children independently of obesity. Mediators Inflamm. 2014; 2014:849031.

30. Huang JH, Lu YF, Cheng FC, Lee JN, Tsai LC. Correlation of magnesium intake with metabolic parameters, depression and physical activity in elderly type 2 diabetes patients: a cross-sectional study. Nutr J. 2012; 11:41.

31. Song CH, Choi WS, Oh HJ, Kim K. Associations of serum minerals with body mass index in adult women. Eur J Clin Nutr. 2007; 61(5):682-5.

32. Lecube A, Baena-Fustegueras JÁ, Fort JM, Pelegrí D, Hernández C, Simó R. Diabetes is the main factor accounting for hypomagnesemia in obese subjects. PLoS One. 2012; 7(1):e30599.

33. Song Y, Li TY, van Dam RM, Manson JE, Hu FB. Magnesium intake and plasma concentrations of markers of systemic inflammation and endothelial dysfunction in women. Am J Clin Nutr. 2007; 85(4):1068-74.

34. Guerrero-Romero F, Rodríguez-Morán M. Serum magnesium in the metabolically-obese normal-weight and healthy-obese subjects. Eur J Intern Med. 2013; 24(7):639-43. 
35. Oliveira AR, Crua KJ, Morais JB, Severo JS, Freitas TE, Veras AL, et al Magnesium status and its relationship with c-reactive protein in obese women. Biol Trace Elem Res. 2015; 168(2):296-302.

36. Zemva A, Zemva $Z$. Ventricular ectopic activity, left ventricular mass, hyperinsulinemia, and intracellular magnesium in normotensive patients with obesity. Angiology. 2000; 51(2):101-6.

37. Corica F, Allegra A, Ientile R, Buemi M. Magnesium concentrations in plasma, erythrocytes, and platelets in hypertensive and normotensive obese patients. Am J Hypertens. 1997; 10(11):1311-3.

38. Bertinato J, Wu Xiao C, Ratnayake WM, Fernandez L, Lavergne C, Wood C, et al. Lower serum magnesium concentration is associated with diabetes, insulin resistance, and obesity in South Asian and white Canadian women but not men. Food Nutr Res. 2015; 59:25974.

39. Suliburska J, Cofta S, Gajewska E, Kalmus G, Sobieska M, Samborski W, et al. The evaluation of selected serum mineral concentrations and their association with insulin resistance in obese adolescents. Eur Rev Med Pharmacol Sci. 2013; 17(17):2396-400.

40. Nielsen FH. Magnesium, inflammation, and obesity in chronic disease. Nutr Rev. 2010; 68(6):333-40.

41. Song Y, Ridker PM, Manson JE, Cook NR, Buring JE, Liu S. Magnesium intake, C-reactive protein, and the prevalence of metabolic syndrome in middle-aged and older U.S. women. Diabetes Care. 2005; 28(6):1438-44.

42. Nielsen FH, Johnson LK, Zeng H. Magnesium supplementation improves indicators of low magnesium status and inflammatory stress in adults older than 51 years with poor quality sleep. Magnes Res. 2010;23(4):158-68.

43. Guerrero-Romero F, Bermudez-Peña C, Rodríguez-Morán M. Severe hypomagnesemia and low-grade inflammation in metabolic syndrome. Magnes Res. 2011; 24(2):45-53.

44. Chacko SA., Song Y, Nathan L, Tinker L, Boer IH, Tylavsky F, et al. Relations of dietary magnesium intake to biomarkers of inflammation and endothelial dysfunction in an ethnically diverse cohort of postmenopausal women. Diabetes Care. 2010; 33(2):304-10.

45. Dibaba DT, Xun P, He K. Dietary magnesium intake is inversely associated with serum C-reactive protein levels: meta-analysis and systematic review. Eur J Clin Nutr. 2014; 68(4):510-6.

46. Mazur A, Maier JAM, Rock E, Gueux E, Nowacki W, Rayssiguier Y. Magnesium and the inflammatory response: potential physiopathological implications. Arch Biochem Biophys. 2007; 458(1):48-56

47. Weglicki WB, Phillips TM. Pathobiology of magnesium deficiency: a cytokine/neurogenic inflammation hypothesis. Am J Physiol. 1992;263(3 Pt 2):R734-7.
48. Nielsen FH, Milne DB, Gallagher S, Johnson L, Hoverson B. Moderate magnesium deprivation results in calcium retention and altered potassium and phosphorus excretion by postmenopausal women. Magnes Res. 2007; 20(1):19-31.

49. Rayssiguier Y, Libako P, Nowacki B, Rock E. Magnesium deficiency and metabolic syndrome: stress and inflammation may reflect calcium activation. Magnes Res. 2010; 23(2):73-80.

50. Severo JS, Morais JBS, Freitas TEC, Cruz, KJC, Oliveira, ARS, Poltronieri F, et al. Aspectos metabólicos e nutricionais do magnésio. Nutr Clín Diet Hosp. 2015; 35(2):67-74.

51. Sarmiento D, Montorfano I, Cáceres M, Echeverría C, Fernández R, Cabello-Verrugio C, et al. Endotoxin-induced vascular endothelial cell migration is dependent on TLR4/NF-B pathway, NAD $(\mathrm{P}) \mathrm{H}$ oxidase activation, and transient receptor potential melastatin 7 calcium channel activity. Int J Biochem Cell Biol. 2014; 55:11-23.

52. Huang L, Ng MN, Chen M, Lin X, Tang T, Cheng H, et al. Inhibition of TRPM7 channels reduces degranulation and release of cytokines in rat bone marrow-derived mast cells. Int J Mol Sci. 2014; 15(7):11817-31.

53. Bae YJ, Choi MK. The estimated daily manganese intake of Korean children aged 11-12. Nutr Res Pract. 2011; 5(6):548-52

54. Patrick L. Nonalcoholic fatty liver disease: relationship to insulin sensitivity and oxidative stress. Treatment approaches using vitamin E, magnesium, and betaine. Altern Med Rev. 2002; 7(4):276-91.

55. Amorim, AG, Tirapegui J. Aspectos atuais da relação entre exercício físico, estresse oxidativo e magnésio. Rev Nutr. 2008; 21(5):563-75.

56. Belin RJ, He K. Magnesium physiology and pathogenic mechanisms that contribute to the development of the metabolic syndrome. Magnes Res. 2007; 20(2):107-29.

57. Moslehi N, Vafa M, Rahimi-Foroushani A, Golestan B. Effects of ora magnesium supplementation on inflammatory markers in middle-aged overweight women. J Res Med Sci. 2012; 17(7):607-14.

58. Rodriguez-Hernandez H, Cervantes-Huerta M, Rodriguez-Moran M Guerrero-Romero F. Oral magnesium supplementation decreases alanine aminotransferase levels in obese women. Magnes Res. 2010; 23(2):90-6.

59. Simental-Mendía LE, Rodríguez-Morán M, Guerrero-Romero F. Oral magnesium supplementation decreases $\mathrm{C}$-reactive protein levels in subjects with prediabetes and hypomagnesemia: a clinical randomized double-blind placebo-controlled trial. Arch Med Res. 2014; 45(4):325-30.

60. Niranjan G, Anitha D, Srinivasan AR, Velu VK, Venkatesh C, Babu MS, et al. Association of inflammatory sialoproteins, lipid peroxides and serum magnesium levels with cardiometabolic risk factors in obese children of South Indian population. Int J Biomed Sci. 2014; 10(2):118-23. 